\title{
ІСТОРИЧНІ СТУДІЇ
}

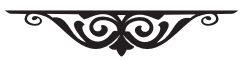

DOI: https://doi.org/

УДК: 94(477):94(100)«05/...»
Володимир Ричка

доктор історичних наук, професор, головний науковий співробітник, сектор досліджень з історії Київської Русі,

Інститут історії України НАН України

(Київ, Україна), wolr@ukr.net

ORCID: https://orcid.org/0000-0001-8037-4106

\section{Мода й ритуал: кодекс убрання в Київській Русі}

\begin{abstract}
Анотація. У статті розглядаються конвенціональні знакові системи кодексу вбрання провідних верств давньоруського суспільства в нерозривній єдності зі сферою їхньої діяльності й поведінки. Мета студії полягає у вивченні комунікативної та символічної природи одягу, осягненні феномену моди у середньовічній Русі та уявлень про сакральну значущість убрання, його ролі в ритуалах щоденної поведінки. Методологічну основу становить принцип історизму, що спирається на впізнаванні релевантної семантичної ізотопії структур повсякденності, комунікативної й ідейно-образної природи вбрання. Наукова новизна. Уперше в українській історіографії комплексно досліджується феномен кодексу вбрання та моди як особливого виду соціальної комунікації Київської Русі. Висновки. З'ясовано комунікативну й символічну природу кодексу вбрання. Одяг і супутні йому речі, що оточували середньовічну людину, мали не тільки утилітарно-споживацький, прагматичний характер - вони диктували манеру поведінки, стиль життя, виконували важливу соціальну функцію. Предметний світ речей і, зокрема, одягу за середньовіччя наділявся знаковим, символічним кодом певних смислів, значень, соціальних комунікацій. Притаманний провідній верстві населення Русі стиль одягання й ритуал щоденної поведінки засвідчував ії інтеґрацію у традиції лицарства, феодальної ідентичності. Обґрунтовано, що мода - це не тільки світ речей та одягу в їхніх зовнішніх формах, а ще й жести, зачіски, звичаї, устрій життя, ритуал щоденної поведінки.
\end{abstract}

Ключові слова: Київська Русь, кодекс убрання, мода, звичаї, ритуал, соціальна комунікація, традиції лицарства.

За середньовіччя вбрання мало полісемантичну функцію. Окрім свого практичного призначення оберігати від холоду й непогоди, воно було одним із маркерів соціального та вікового стану людини. За словами Ж. Ле Гофрфа, кодекс убрання й кодекс застілля у феодальному суспільстві «діяли особливо ефективно, адже виступали як основний критерій при визначенні соціального статусу людини та посідали важливе місце у системі цінностей. Видимість, що поставала крізь призму цих правил, набувала особливої переконливості» ${ }^{1}$. Здійснена у цій статті спроба аналізу кодексу вбрання давньоруських спільнот у його нерозривній едності зі

\footnotetext{
1 Ле Гофбб Ж. Средневековый мир воображаемого / Пер. с фр. - Москва, 2001. - С.235.
} 
сферою їхньої діяльності й поведінки покликана глибше осягнути знакову систему соціальної організації Київської Русі, зокрема з'ясувати природу та «мову» іерархічних зв'язків між людьми, про яку сигналізуе їхне вбрання.

Уже на ранніх етапах історичного життя людських колективів з'являеться особливий, притаманний певним групам людей стиль одягання, добору матеріалу для виготовлення одягу та супутніх убранню аксесуарів. Перебуваючи 922 р. у складі арабського посольства, Ібн-Фадлан побачив та описав побут русів, котрі прийшли зі своїм крамом на Волгу. Він повідав про те, що власних небіжчиків вони одягають у найкраще вбрання, яким ті користувалися за життя, а саме «широкі штани, панчохи, чоботи, куртку і свиту з шовку з золотими ґудзями, а на голову - шапку 3 шовку і соболя» ${ }^{2}$. Неодмінним атрибутом верхнього одягу чоловіків був плащ ним огортали половину тулубу так, щоб можна було вправно вихопити меч або ніж. Плащі, за словами Ібн-Фадлана, прикрашалися гаптованими візерунками. Ці руси були представниками однієї з численних мобільних військово-торговельних корпорацій, із діяльністю яких у Східній Свропі пов'язуеться виникнення на рубежі IX-X ст. на берегах Середнього Дніпра військово-політичної структури, що стала відомою під назвою Русь, Руська земля.

З утвердженням Київської Русі на міжнародній арені, подальшим розвитком торговельних зв'язків із Візантією, країнами арабського Сходу й латинського Заходу обсяги обміну помітно зростали. Традиційними товарами збуту були мед, віск, хутро. Для дружинників Київської Русі епохи правління Олега Віщого та князя Ігоря грабіжницькі війни були головним джерелом набуття дорогого вбрання та озброєння. Намовляючи останнього вирушити в похід у землю древлян вони, за словами старокиївського літописця, говорили: «Отрици Свђнельжи (воєводи Свенельда - B.P.) изодълися суть оружьемъ и порты . а мы нази . поиди княже с нами в дань . да и ты добеши и мы» ${ }^{3}$.

Серед предметів розкоші, що ввозилися до країни, помітне місце посідали золоті та срібні прикраси й посуд, бойові обладунки, дорогоцінні тканини, різноманітні аксесуари для одягу. Сповіщаючи про тріумфальне повернення князя Олега до Киева з переможного походу на Візантію 911 р., літописець зазначав: «И приде Олегь к Киеву . неся злато и паволоки и овощи и вина . и всякое узорочье» ${ }^{4}$. Паволоки, «узороччя» - усталений топос давньоруського літописання. Ці товари виступають неодмінним атрибутом в описах воєнно-політичних і торговельних зв'язків Київської Русі з Візантіею. Княгиня Ольга під час свого візиту до Константинополя в 955/957 pр. отримала з рук імператора «злато и сребро. паволоки и с[о]суды различныя» ${ }^{5}$. Багатства Візантії були предметом жадань правлячої верхівки Русі, котра прагнула скрасити своє життя небаченими доти дорогими шатами, зброею.

Великою честю для київських князів (як і багатьох інших "варварських» вождів) було отримати за свої послуги щось зі вбрання чи регалій влади з рук самого візантійського імператора. Так, Константин Багрянородний (Пурпурогенет) у своему трактаті «Про управління імперією» (944-959рр.), нарікаючи на домагання «північних і скіфських» народів «послати їм що-небудь із царського убрання,

\footnotetext{
${ }^{2}$ Цит. за: Грушевський М.С. Виїмки з жерел до історії України-Руси: до половини ХІ в. // Його ж. Твори у 50 т. - Т.6: Серія «Історичні студії та розвідки (1895-1900). - Л., 2004. - С.46. Пор.: Путешествие Ибн-Фадлана на Волгу / Пер. и комм. А.П.Ковалевского. - Москва; Ленинград, 1939.

3 Лаврентьевская летопись // Полное собрание русских летописей (далі - ПСРЛ). - Т.1. - Москва, 1962. Стб.54.

${ }^{4}$ Там же. - Стб.32.

5 Там же. - Стб.61.
} 
вінців чи й мантій заради якоїсь їхньої служби або послуги», радив своєму синові Роману відповідати «варварам», що ці речі виготовлено не людьми, а самим Богом, і через ангела послані вони першому християнському володареві Константинові Великому з повелінням покласти їх у церкві Св. Софії. Тож «не мають права ані василевс, ані патріарх, ані хто-небудь інший брати ці шати або вінці зі святої Божої церкви. Великий страх тяжіє над тими, хто посміє порушити цей Божий заповіт» ${ }^{6}$

Імператорське вбрання, його форма, матеріал і колір мали сакральне значення. Підданим було суворо заборонено використовувати для виготовлення одягу пурпурні паволоки. Відрізи ціеї тканини, як і вироби з неї заборонялося продавати іноземцям. Посланий імператором Оттоном I із дипломатичною місією до Константинополя в 968 р. кремонський єпископ після свого повернення обурювався тим, що на митниці в нього відібрали п'ять пурпурових плащів. У руськовізантійській угоді 944 р., укладеній князем Ігорем 3 імператорами Романом i Константином, чітко зазначалося, що руські купці не можуть купувати на ринках Царгорода найдорожчі паволоки: «Входяще же русь в градъ . да не творять пакости и не имеютъ власти купити паволокъ лише по 50 золотникъ и от тьхъ паволокъ аще кто купить . да показываетъ цареву мужю . и то е запечетаеть и дасть имъ» ${ }^{7}$ Найдорожчі пурпурові паволоки, предмет гордості Візантії, як уже зазначалося, було заборонено вивозити з країни.

Між тим для більшості народів середньовічного світу, «котрі не мали можливості споглядати її чудеса, Візантія була джерелом майже всіх багатств, адже звідти доставляли найцінніші товари її власного чи іноземного походження - розкішні тканини (наприклад шовк, секрет якого візантійці вирвали в Китаю в VI ст.), надходила повноцінна до кінця XI ст. золота монета [...]. Як же спокушали такі багатства!». Ними "греки» відкуплялися від зазіхань своїх войовничих сусідів. Це був переконливий спосіб упокорити небайдужих до розкошів «варварських» вождів. За свідченням історика Нікіти Хоніата, імператор Мануїл Комнін,

«знаючи, що всякий варвар ласий на подарунки, забажав одного разу вразити сельджуцького султана з Іконії на ймення Килич-Арслан (1156-1192 рр.) своїми скарбами: Він наказав в одному з прекрасних палацових покоїв розкласти по порядку все, що надумав передати тому в дар. Тут було золото і срібло в монетах, дорогоцінний одяг, срібні й золоті чаші, розкішні тканини та інші чудові речі, звичні для ромеїв, але у варварів рідкісні, а навіть зовсім небачені»9.

Візантійський імператор Константин Багрянородний у життеписі свого діда Василія Македонянина стверджував, що той нахилив «нарід руський, необорний і безбожний» до угоди, «щедро роздаючи одежі золоті, срібні і шовкові» ${ }^{10}$. У розпал розв'язаної київським князем Святославом війни з Візантією на Балканах прибулі до нього імператорські посланці розклали перед останнім «злато и паволоки», намагаючись досягти миру на вигідних для себе умовах. За свідченням «Повісті временних літ» Святослав «не зрђ на ня . и повель схоронити» ${ }^{11}$.

\footnotetext{
6 Константин Багрянородный. Об управлении империей (Текст, перевод, комментарий). - Москва, 1991. - C.54-57.

7 Лаврентьевская летопись. - Т.1. - Стб.49.

8 Ле Гофбб Ж. Цивилизация средневекового Запада. - С.135.

9 Nicetae Choniatae. Historia / J.-P. van Dieten. - Barolini et Novi Eboraci, 1975; Никита Хониат. История / Под ред. В.И.Долоцкого, В.Чельцова. - Т.1. - Рязань, 2003. - С.132.

10 Грушевський М.С. Виїмки з жерел до історії України-Руси: до половини ХІ в. - С.68.

11 Лаврентьевская летопись. - Т.1. - Стб.71.
} 
Зберігся опис зовнішнього вигляду та вбрання князя Святослава Ігоревича, котрий після затвердження мирної домовленості зустрівся з імператором. Убраний у визолочений обладунок Цимісхій під'їхав на чолі озброєних вершників до берега Дунаю, натомість Святослав прибув на місце зустрічі на човні. Візантійського хроніста Лева Диякона, який описав цю подію, вразила скромність одягу руського володаря та його зовнішність. А виглядав він так:

«Середнього зросту, не занадто високий, але й не низький, брови мав густі, очі сині, ніс короткий, борода оголена, на верхній губі густе й довге волосся, голова зовсім обголена, з одного боку висів чуб, що означало значний рід; шия здорова, плечі широкі, і взагалі дуже добре був збудований; здавався якимсь понурим і диким; в однім усі висіла золота сережка, оздоблена двома перлинами, з карбункулом посередині, одіж на нім була біла, нічим не різнилася від інших, окрім чистоти» ${ }^{12}$.

Натомість в одній із мініатюр хроніки Іоанна Скіліци князя Святослава зображено у вінці, золотому «грецькому» одязі, із довгим русявим волоссям, у пурпурових штанях ${ }^{13}$. Такий образ київського володаря контрастуе 3 повідомленням «Повісті временних літ» і наведеним вище словесним портретом Святослава пера Лева Диякона. Обидва джерела засвідчують невибагливий військово-польовий побут князя, скромність його вбрання. Однак представлений ними зовнішній вигляд також став виявом особливого, нехай і обмеженого в умовах бойових дій знакового символізму його владних повноважень. Отож зображені у творі Скіліци великокнязівські шати й регалії слід розглядати не тільки як данину художньому канону мініатюриста XII ст., але як утілення ідеологізованих знакових іконічних символів, що співвідносилися з візантійською системою сприйняття монаршої гідності та влади.

Із прийняттям нової релігії й долученням Київської Русі до сім’ї християнських народів її володарі змогли втамувати свої прагнення, мовлячи словами М.С.Грушевського, «приодягнутись ареолою царгородського двору» та, зокрема, отримати атрибути імператорського облачення, peraлії влади, які б стрімко вивищили престиж київського князя, надали йому слави. Історик уважав дуже правдоподібним, що хреститель Русі разом із рукою візантійської принцеси дістав якісь інсигнії, зокрема вінець кесаря, та ним коронувався: «Володимир, будуючи руську державу, забажав для сієї будови візантійського цементу [...] ми знаємо, що він казав робити собі монету з своїм портретом в цісарських реґаліях; ми не знаємо, але можемо догадуватись, що з його посвояченням з візантійським двором в'язалось надання якогось візантійського титулу, візантійських інсигній» ${ }^{14}$. Своєчасно надана Володимиром імператорові Василіеві II військова допомога порятувала македонську династію від узурпатора Варди Фоки, котрого було розгромлено в битві під Константинополем навесні 989 р. Отож уявляеться малоймовірним, що єдиною винагородою київському князеві стала лише рука принцеси Анни.

Родинне споріднення хрестителя Русі з імператорським двором було напевно пов'язано 3 даруванням йому високого візантійського придворного титулу та відповідних інсигній. Це підтверджується тим, що на карбованих Володимиром монетах він представлений з «атрибутами імператорського облачення, які ми бачимо на

12 Див.: Грушевський М.С. Виїмки з жерел до історії України-Руси: до половини XI в. - С.107.

${ }^{13}$ Кондаков Н.П. Греческие изображения первых русских князей // Сборник в память святого равноапостольного князя Владимира. - Санкт-Петербург, 1917. - С.14-15.

${ }^{14}$ Грушевський М. Історія України-Руси: В 11 т., 12 кн. - Т.1: До початку ХІ в. - К., 1991. - С.507. 
візантійських монетах, із візантійською імператорською короною на голові. У правій руці він тримає скіпетр із хрестом. Одяг Володимира відповідає імператорському» ${ }^{15}$. Викарбуване на цих золотих і срібних монетах зображення відбиває очевидно реальні портретні риси князя ${ }^{16}$. Відзначаючи такі оригінальні деталі обличчя Володимира, як грізно насуплені брови, великий м'ясистий ніс, довгі вуса та голене енергійне підборіддя, М.П.Сотникова дійшла висновку про те, що це зображення - найдавніший руський портрет $\mathrm{X} \mathrm{cт.}{ }^{17}$ На відомих автентичних іконографічних зображеннях великий київський князь постає вдягнутим в обшитий золотим широким галуном плащ (корзно), застебнутий на правому плечі масивною підковоподібною коштовною фрібулою. Його голову вінчає дорогоцінний вінець або корона, прикрашена смарагдами та іншим коштовним камінням. Саме в такому вигляді, із хрестом у правиці, зображено Володимира на карбованих ним золотих і срібних монетах ${ }^{18}$.

Парадний, багато оздоблений одяг став невід'ємною частиною знакової системи владних атрибутів носіїв верховної влади. Про церемоніальне вбрання князівської родини можна скласти уявлення на основі реконструйованої С.О.Висоцьким фррескової композиції, розміщеної під арками хорів Софії Київської, де зображено Ярослава Мудрого та членів його сім'і19. За спостереженнями дослідника на малюнку А. ван Вестерфельда, зробленому у середині XVII ст. з тоді ще вцілілої фррески XI ст. Ярослав представлений убраним у плащ-корзно з вигаптуваними на ньому зображеннями геральдичного орла ${ }^{20}$. У такому ж плащі-багряниці зображено князя Ярослава Всеволодовича на фрресці XII ст. у Спасо-Нередецькій церкві в Новгороді. Слід зауважити, що у Візантії подібні плащі або мантії мали назву «орлів» і входили до складу облачення вищих сановників імператорського двору ${ }^{21}$.

Дороге вбрання та інші візантійські добра - головні джерела поповнення скарбниці Ярослава Мудрого - під охороною зберігалися у князівських палатах. Значна частина цих багатств потрапила до Києва вочевидь завдяки його майбутньому зятеві норвезькому конуніові Гаральдові Суворому, котрий тривалий час перебував на візантійській службі. Закоханий в Ярославову дочку Єлизавету (Елісів) він усі свої трофеї, здобуті під час походів в Африці й на Сицилії, надсилав «на зберігання Ярицлейву конунгу». В Ярослава, за свідченням скандинавських саг, «було стільки добра, скільки ніхто в північних країнах не бачив у власності одніеї людини. Гаральд тричі ходив в обхід палат, поки перебував у Міклагарді (Царгороді - B.P.). Там було у звичаї, що всякий раз, коли помирав конунг греків, верінги (особиста Івардія імператора - B.P.) мали право обходити всі палати, де знаходилися його скарби, і кожен міг залишити за собою те, на що зуміє накласти руку» ${ }^{22}$. Схоже, Гаральдові вдалося добре «накласти руку» на імператорські скарби, якщо значна

15 Левченко М.В. Взаимоотношения Византии и Руси при Владимире // Византийский временник. - Т.7. Москва, 1953. - С.212.

16 Толстой И.И. Древнейшие русские монеты Х-ХІ вв. - Санкт-Петербург, 1893. - С.16-17.

17 Сотникова М.П. Сребреники киевского клада 1876 г. // Нумизматика и сфрагистика. - 1968. - №3. - С.119; Её же. Древнейшие русские монеты Х-ХІ вв.: Каталог и исследование. - Москва, 1995. - С.174.

18 Сотникова М.П., Спасский И.Г. Тысячелетие древнейших монет России: Сводный каталог русских монет Х-ХІ вв. - Ленинград, 1983. - С.115-139.

19 Высоцкий С.А. Светские фрески Софийского собора в Киеве. - К., 1989. - С.64-112. Див. також: Коренюк Ю. Маловідомі аспекти реставрації мозаїк і фресок Софії Київської середини минулого століття // Ruthenica: Щорічник середньовічної історії та археології Східної Європи. - Т.XV. - К., 2019. - С.225-231.

${ }^{20}$ Висоцький C.В. Герб Київської Русі за часів Ярослава Мудрого // Старожитності Русі-України. K., 1994. - C.118-119.

${ }_{21}^{21}$ Кондаков Н.П. Изображение русской княжеской семьи в миниатюрах XI в. - Санкт-Петербург, 1906. - С.38.

${ }^{22}$ Сага о Харальде Суровом // Снорри Стурлуссон. Круг земной [Литературные памятники]. - Москва, 1980. - C.405, 411. 


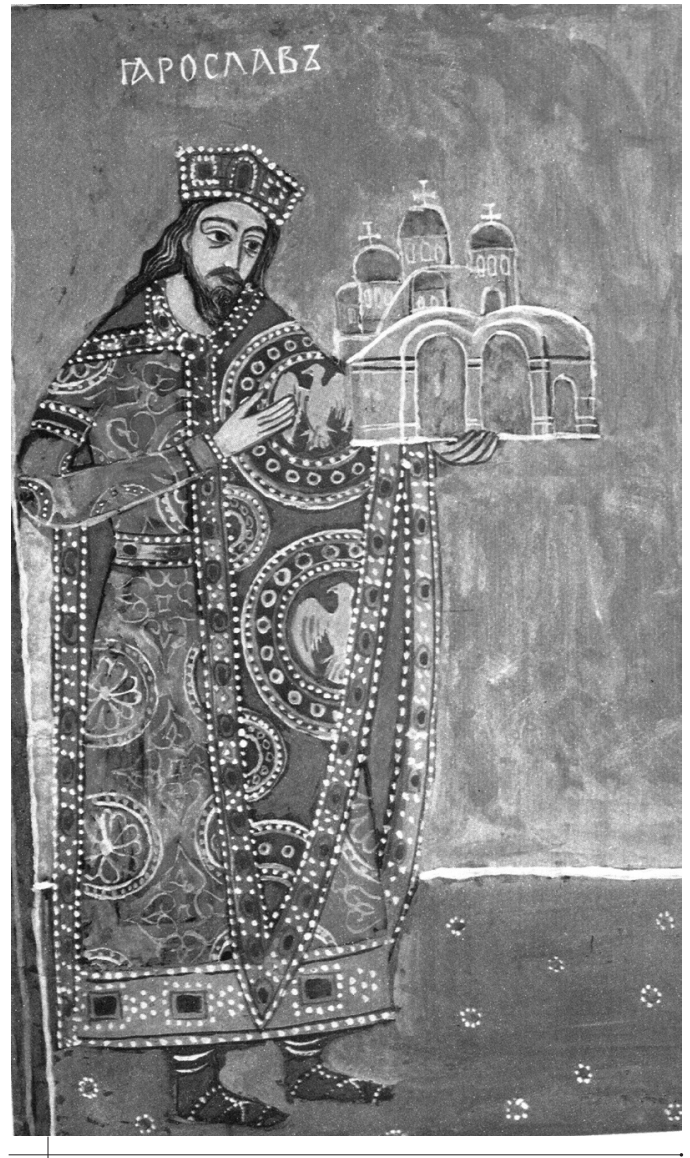

Ярослав Мудрий у церемоніальному княжому вбранні. Реконструкція С.О.Висоцького та Ю.Ф.Коренюка за фраґментом фрески Софійського собору в Києві й малюнком А. ван Вестерфельда 1651 р. ïх частина опинилася на берегах Дніпра, куди, полишивши візантійську службу, він зрештою повернувся. Тут норвезький конунг перезимував, а потім разом з Єлизаветою вирушив на свою Батьківщину.

3 імператорського гардеробу походили, очевидно, і шість дорогих каптанів, виявлених під час археологічних розкопок Чингульського кургану кінця XII - початку XIII ст. на березі річки Молочної. Похований тут вождь-кочівник був одягнений у каптан зі щільного червоного шовку зі вставками золотого шитва на синьому тлі. Шиттям було прикрашено всю лицьову сторону, верхні частини рукавів і зап'ястя. Комір каптана і круглу шапочку обкладено позолоченими бляшками зі вставками самоцвітів. Контури візерунків унизані перлами. Ще п'ять таких каптанів лежали у сувоях біля ніг небіжчика ${ }^{23}$. Південні сусіди Русі половці не поступалися руським князям у любові до вишуканого вбрання i прикрас. Яскрава й самобутня орієнтальна культура Половецького поля, своєю чергою, справляла вплив на стиль одягання та моду руських спільнот.

За свідченням «Повісті временних літ» син Ярослава Мудрого

Святослав, котрий княжив у Киеві 1073-1076 рр., успадкував чималі багатства, якими вихвалявся перед німецькими послами, що прибули до Киева в 1075 р.: «Показа имъ багатство свое [...] бещисленое множьство злато и сребро и паволокы» ${ }^{24}$. Переписаний із болгарського оригіналу «Ізборник» 1073 р. на початку містить мініатюру із зображенням самого Святослава, його дружини та чотирьох синів. Ретельно передано деталі князівського парадного одягу. Художники продемонстрували добру обізнаність із мистецтвом Візантії, зокрема майстерністю імператорських мініатюристів, для яких важливим було передати не стільки людську індивідуальність, скільки через кольорові відтінки елементів одягу втілити чесноти «праведного» князя і членів його родини. Синів Святослава зображено в малиновому одязі з червоною облямівкою, золотими комірами, у підперезаних поясами каптанах.

${ }^{23}$ Отрощенко В.В., Рассамакін Ю.Я. Половецький комплекс Чингульського кургану // Археологія. Вип.53. - К., 1986. - С.14-36.

24 Лаврентьевская летопись. - Т.1. - Стб.198. Наприклад, за 5 ліктів шовкової яскраво-червоної тканини та 50 гривень кун можна було придбати, як у випадку волинського князя Володимира Васильковича, ціле село (див.: Ипатьевская летопись // ПСРЛ. - Т.2. - Стб.904). 
В одному зі списків сказання XIV ст. про святих мучеників Бориса i Гліба обох синів князя Володимира зображено у червоних плащах, довгих підперезаних зеленого кольору свитах, із жовтою (золотою) накладкою по подолу та 3 вузькими рукавами ${ }^{25}$. На мініатюрах хроніки Іоанна Скіліци, які ілюструють обмін посольствами між князем Володимиром Всеволодовичем і візантійським імператором Константином Мономахом, київський князь сидить на золотому троні, у царському вінці, червоних чоботях і золотому жупані ${ }^{26}$. Однак, як уявляеться, усі ці зображення - не «замальовка 3 натури», не дзеркальний відбиток князівського побуту, а лише художня метафора, що поєднала у собі достовірні й уявлені зразки канону монаршого вбрання та ритуалу влади.

Найбільш яскравим у літературі Київської Русі став опис убрання «короля» Данила Романовича, уміщений під 1252 р. у складі Галицько-Волинського літопису. На чолі руських полків, споряджених «татарським» озброєнням, він

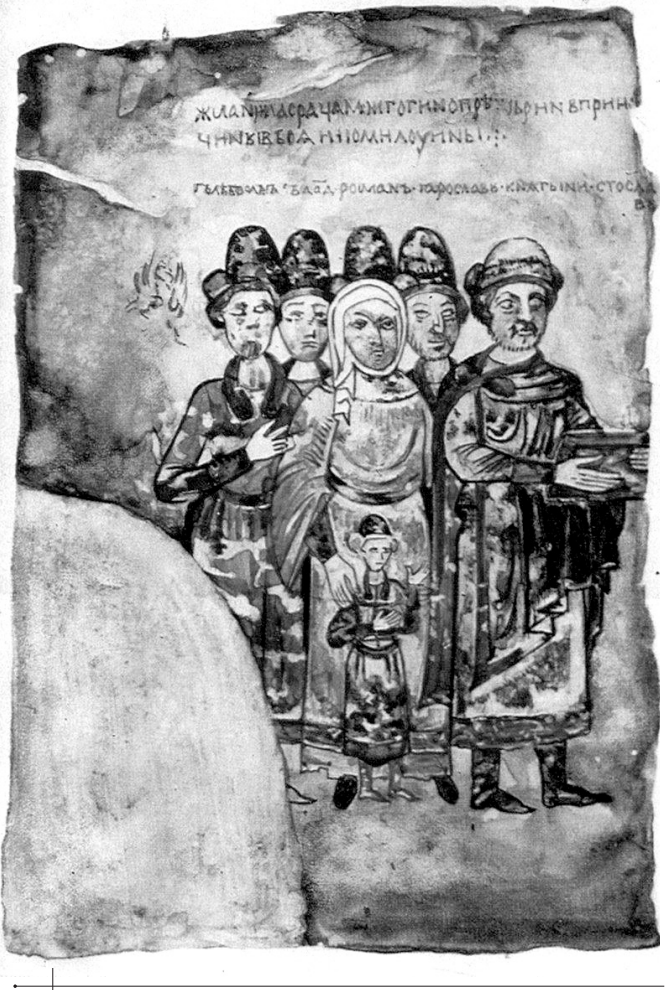

Родина Святослава Ярославича. Мініатюра з «Ізборника» 1073 р. гордовито їхав обіч угорського монарха «по обычаю Роуску» на зустріч із прибулими до нього посланцями німецького імператора: «Бь бо конь под нимь дивлению подобенъ, и сьдло от злата, жьжена, и стрьлы и сабля златомъ оукрашена. Иными хитростьми, якоже дивитися: кожюхъ же оловира Грџького, и кроуживы златыми плоскоми ошить, и сапози зеленого хъза шити золотом» ${ }^{27}$.

Багато хто з істориків у цьому описі Данилового вбрання вбачає руку безпосереднього очевидця. Одяг виписано з реальними деталями, що виходять за межі літописного трафрарету. Проте давно помічено, що цей опис текстуально грунтується на запозичених руським книжником фразеологізмах хроніки Іоанна Малали. Так, за спостереженнями О.С.Орлова, у книзі XVII «Еллінського літописця» описуеться одяг лазсько-перського царя Чафрія, дарований йому імператором Устином як інсигнії влади. Отже носив він «вђнецъ Румескъ», але білий «оскрилъ», і мав «в багра место нашву злату плоску [...] сапози же его беша от своея ему страны черъвени с бисеры, пръскимъ образомъ, тако же и пояс ему съ бисеры». При цьому дослідник не виключав можливості, що на зображення Данила окрім Чафрія наклалися ще й риси Дарія Перського з «Александрії, а саме з розповіді про те, як, приймаючи Александра Македонського, «седяше Даріи въ венци, иже бе съ каменіемъ,

\footnotetext{
25 Срезневский И.И. Древние изображения великого князя Владимира и великой княгини Ольги // Древности: Археологический вестник, издаваемый Московским археологическим обществом. - Т.1. - Москва, 1868. - С.3. Пор.: Петров Н. Древние изображения св. Владимира // Владимирский сборник в память девятисотлетия крещения Руси. - К., 1888.

26 Кондаков Н.П. Греческие изображения первых русских князей. - С.14-15.

27 Ипатьевская летопись. - Т.2. - Стб.814.
} 
в ризе червлене, яже бе вавилоньскы ткана златым пряденом, и в багре царьстемъ, и в сапозехъ златыхъ, съ камениемъ деланы по лысту его, скипетры обаполы его, палъци же тмами около его». Після бесіди Дарій, «дръжа за руку Александра и веде его въ полату свою. И се же знамение добро имяше Александр, за руку приведенъ отъ врага. И пришед во внутрь полаты своя, абие възлеже пръвее Александр на вечери Дарьеви» ${ }^{28}$. Із такою гостинністю Дарія зіставляється завершення літописної оповіді 1252 р. про виправу Данила. Похваливши його руський «обичай», угорський король «просися оу него въ станъ . зане зной бъ велик дне того онъ же я и за роукоу и веде его въ полатоу свою . и самъ совлочашеть его . и облачашеть и въ порты свођ и таку честь творяшеть» ${ }^{29}$. Прагнучі звеличити Данила, літописець у літню спеку навіть убрав свого героя у зимовий кожух.

Данилові пощастило мати прихильного «портретиста» - укладача чи редактора Галицько-Волинського літопису. «Повний щирої симпатії й поважання до свого «короля», сей літописець, - зауважував М.С.Грушевський, - з замилованням слідить за подвигами свого героя, не упускає нічого, що могло б піднести його славу й чесноти, та досить зручно налягає на ясні фрарби, малюючи Данила, і на темні в оправах його противників» ${ }^{30}$. Засуджуючи самоправство галицьких бояр, автор джерела вирізняв із-поміж них Доброслава Суддича. Цей попів онук укняжився був у Галичі «и грабяше всю землю . и въшед во Бакоуту . все понизья прия . безъ княжа повелениа». Глузуючи над зарозумілістю й марнославством можновладця, літописець стверджував, що той в одній лише сорочці, але з великою пихою приїхав до Данила («едоучю Доброславоу во одинои сорочьць . гордящоу ни на землю смотряшю») ${ }^{31}$. Цим він сам себе оконфузив, адже з'явитися на людях в одній сорочці було ганьбою для правителя. Кепкуванням просякнута й оповідь Никонівського літопису про втечу Юрія та Ярослава Всеволодовичів із поля Липецької битви 1216 р.: «И прибъже князь Юрьи въ Володимеръ во единой сорочиць точию, и брать его князь Ярославъ такоже во единой сорочиць, трехъ коневи оудушивъ, а на четвертом пригна Володимеръ» ${ }^{32}$.

Значну частину нормативного князівського гардеробу складали дорогі, розшиті золотими й шовковими нитками довгополі сорочки. Круглий або квадратний глибокий виріз коміра обшивався золотом, а подеколи й самоцвітами ${ }^{33}$. Такий комір-опліччя міг бути пристібним або наглухо пришитим. Вони захоплювали уяву сучасників: «Паволока испещрена многими шелки, красно лице являеть» ${ }^{34}$. Похвали київського книжника початку XII ст. удостоїлась добра господиня дому, яка здатна «одьнья створить мужеви своему очерьвлена и багряна». У такому одязі «взоренъ бываеть во вратъхъ муж ея . аще сядеть на сонмищи . съ старци и съ жители земли» (Пр.31: 23) ${ }^{35}$. Виткані золотом «червоні руські убрання» набули популярності, за свідченням скандинавських саг, і серед чужоземних вельмож. Особливо пишно були розшиті руками вправних майстринь князівські плащі-корзна. Пологи також

\footnotetext{
28 Орлов А.С. К вопросу об Ипатьевской летописи // Известия Отделения русского языка и словесности АН. T.XXXI. - Петроград, 1926. - С.105-106.

29 Ипатьевская летопись. - Т. 2. - Стб.814-815.

30 Грушевський М.С. Історія України-Руси. - Т.3: До року 1340. - К., 1993. - С.90.

31 Ипатьевская летопись. - Т.2. - Стб.790.

32 Летописный сборник, именуемый Патриаршей или Никоновской летописью // ПСРЛ. - Т.9. - Москва, 2009.

33 Брайчевская E.A. Летописные данные о древнерусском мужском костюме Х-ХІІІ вв. // Земли Южной Руси в IX-XIV вв. (История и археология). - К., 1985. - С.119-120.

34 Слово Даниила Заточника по редакциям XII и XIII вв. и их переделкам [Памятники древнерусской литературы, вып.3]. - Ленинград, 1932. - С.44.

35 Лаврентьевская летопись. - Т.1. - Стб.81.
} 
оздоблювалися золотистою облямівкою. Мода рясно прикрашати плащі гаптуванням та різними малюнками для надання вбранню сакрально-захисної сили була поширеною в багатьох країнах середньовічного Заходу і Сходу. Плащ застібався на плечі за допомогою виготовленої з дорогоцінного металу фібули.

Досить складно виокремити окремі деталі спіднього вбрання, яке в давньоруському писемному лексиконі відоме під узагальненою назвою «пърты» або «пъртове» ${ }^{36}$. Очевидно, цими словами позначалися штани (сподні) й сорочка («срачиця»). За свідченням арабського письменника першої половини Х ст. Ібн-Русте (помилково-Ібн-Даста), руси носили широкі сподні, на пошиття яких ішло 100 ліктів тканини на кожні: «Одягаючи такі сподні, збирають їх коло коліна і прив’язують до нього» ${ }^{37}$. Цей одяг був зручним у бою. Широкополими залишалися й відомі з літописних джерел XII-XIII ст. князівські «порти». Аби убезпечитися від замаху під них можна було надягти непомітну сторонньому оку металеву кольчугу. Розповідаючи про ворожнечу поміж мешканцями Полоцька та їхнім князем Ростиславом Глібовичем, Київський літопис під 1158 р. сповіщав, що містяни мали намір схопити його під час улаштованої ними на Петрів день святкової братчини. Але той, дізнавшись про такий задум, надягнув під одежу захист: «Он же ьха к ним изволочивъся въ бронь . под порты . и не смьша на нь дъръзнути» ${ }^{38}$.

Прикрашений золотим шитвом пояс перехоплював одяг у талії, його кінці спускалися вільно вниз. Такий пояс був примітною частиною вбрання аристократів. Виготовлені зі срібла й золота парадні князівські пояси ставали фрамільними реліквіями, що разом з іншими цінними речами передавались у спадок від батька до сина. Відчуваючи наближення смерті волинський князь Володимир Василькович 1288 р. 3-поміж іншого майна «разда оубогым [...] и. поясы золотыи отца своего и серебрянье . и свое иже бяше по отци своемъ стяжалъ» ${ }^{39}$. Знаковою річчю були пояси й для інших верств вільного населення Київської Русі. Також пояс - частина обладунку та символ воїнської гідності дружинників. Відомі за матеріалами археології їхні пояси складалися з набірних зазвичай срібних блях і різноманітних пряжок, на яких застібалися піхви меча та шкіряний гаманець. Разом із багато орнаментованою кінською упряжжю вони були суттєвим елементом елітарної дружинної культури, нав'язуючи манеру поведінки, створюючи навколо себе певний соціокультурний контекст.

Важливим атрибутом убрання провідних суспільних верств, знаком княжої гідності була м'яка сфрерична шапка 3 хутряною околицею ${ }^{40}$. Зимовий одяг виготовлявся з дорогого хутра бобрів і соболів. Київська Русь була головним постачальником на ринки Візантії та Західної Свропи окрім бобрового та соболиного ще й хутра білок, куниць тощо. "Соболяче корзно» з Русі набуло широкого вжитку у західноєвропейському лицарському геральдичному лексиконі. Княжим взуттям слугували високі чоботи з м’якої кольорової шкіри, синього, жовтого й червоного сап'яну. Носити шкіряне взуття, зокрема чоботи, могли дозволити собі лише заможні верстви населення, а бідніші люди взувалися в постоли. Коли у середині 980-х pp.

\footnotetext{
36 Див.: Срезневский И.И. Материалы для словаря древнерусского языка по памятникам письменности. Т.2. - Санкт-Петербург, 1895. - Стб.1753-1755.

37 Грушевський М.С. Виїмки з жерел до історії України-Руси: до половини ХІ в. - С.53. Пор.: Известия о хазарах, буртасах, болгарах, мадьярах, славянах и русах Абу-Али Ахмеда бен Омара Ибн-Даста, неизвестного доселе арабского писателя Х в. по рукописи Британского музея в первый раз издал, перевёл и объяснил Д.А.Хвольсон. - Санкт-Петербург, 1869.

38 Ипатьевская летопись. - Т.2. - Стб.495.

39 Там же. - Стб.914.

40 Арциховский А.В. Одежда // История культуры Древней Руси. - Т.1. - Москва; Ленинград, 1948. - С.247-248.
} 
київський князь Володимир Святославич захопив Волзьку Булгарію його воєвода Добриня, оглянувши полонених, нібито сказав: «Оже суть вси в сапозђх . сим дани нам не даяти . поидемъ искать лапотниковъ» ${ }^{41}$.

За середньовіччя предметний світ речей i, зокрема, одягу та аксесуарів наділявся знаковим, символічним кодом певних смислів, значень, соціальних комунікацій. Наприклад, згода нареченої на весілля зі своїм обранцем виявлялася в передачі тому в дар убрання, як-от у випадку однієї норвезької принцеси ним став плащ із золотим шитвом і срібний пояс ${ }^{42}$. Жаданою честю для древлянського князя Мала був весільний дарунок київської княгині Ольги - «очьрвлена и багряна одъянья, вси жемьчюгом иссаджены» ${ }^{43}$. Кожній важливій події приватного й публічного життя княжої родини відповідав ретельно продуманий кодекс одягання. Знаковими віхами були хрестини, оперізування, перше посадовлення на коня, весілля, похорон.

Бажання дбати про свою зовнішність, а отже і про одяг, спричинило попит на дзеркала. Бронзові та посрібнені вони стали корисним винаходом античних народів, даруючи задоволення юним красуням, а жінкам старшого віку - печаль. Такій «жене бо злообразне», на думку одного літературного дотепника, «не достоит в зерцало приницати, да не в большую печаль впадет, ввозревше на нелепостьство лица своего» ${ }^{44}$. Інтегровані у традиції лицарства чоловіки, що бачили у дзеркалах відображення власного обличчя, також мусили більше думати про свою зовнішність, давати раду вусам і бороді, не забувати про гребінець та ножиці. Адже мода - це не тільки світ речей, прикрас, одягу, що оточує людину, а ще їі зачіска, устрій життя, звичаї, манери поведінки.

Коли прибула до Венеції для шлюбу з дожем візантійська принцеса (кінець XI ст.) почала за обідом їсти золотою виделкою, їй натякнули, що доброю манерою буде брати м'ясо руками із загальної тарелі. Століттям раніше дружинники київського князя Володимира Святославича нарікали, що дав він їм їсти дерев'яними ложками, а не срібними: «Зло есть нашим головамъ . да нам ясти деревяными лъжицами . а не сребряными» ${ }^{45}$. Загартовані в далеких походах ветерани демонстрували за обідом на княжому дворі добрі манери, що було наукою київським вахлаям. Золоті та срібні столові прибори, як засвідчують археологічні артефакти, стали окрасою столу аристократа в Київській Русі, проте невідомо, чи вміли його гості ними користуватися. У часи середньовіччя для придворних на европейському Заході було написано чимало настанов, що мали навчити їх добрих манер за столом. Більшість заборон пов'язувалися з плюванням, сяканням та виділенням iз кишківника травних газів. Як з усім цим давали собі раду придворні київських князів, можна тільки здогадуватися. Проте у всі часи «мистецтво savoir vivre, жити, вимагає куди більшого, ніж здатності контролювати свою слину, сфрінктер і вміння користуватися срібними столовими приборами» ${ }^{46}$.

Убрання благородного лицаря, зокрема здалека помітний у натовпі плащкорзно, було не тільки візуальною ознакою воїнської гідності, а ще й своерідним оберегом. Під час заворушень у Києві 1147 р., коли над чернігівським князем Ігорем, що його ув'язнив Ізяслав Мстиславич, нависла небезпека розправи, а натовп киян

\footnotetext{
41 Лаврентьевская летопись. - Т.2. - Стб.84.

42 Сага об Олафе Святом // Снорри Стурлуссон. Круг земной. - С.220.

43 Летописец Переяславля Суздальского. - Москва, 1851. - С.11.

44 Слово Даниила Заточника по редакциям XII и XIII вв. и их переделкам. - C.47.

45 Лаврентьевская летопись. - Т.1. - Стб.126.

46 Дейвіс Н. Європа: Історія / Пер. з англ. П.Таращук, О.Коваленко. - К., 2001. - С.361.
} 
рушив до монастиря Св. Феодора, де було пострижено Ігоря, Ізяславів брат князь Володимир, намагаючись урятувати в'язня, скочив на коня й перегородив дорогу до монастирських воріт: «И срьте и Володимиръ въ вратъх манастырских [...] и скочи Володимиръ с коня и огорну и коръзномъ . река Кыяномъ брате моя не мозите сего створити зла ни оубиваите Игоря» ${ }^{47}$. Утім урятувати Ігоря не вдалося. Його понівечене тіло потягли зі Мстиславого двору через Бабин торжок до княж-двору, де і «прикончаша и». Бездиханний труп поклали на воза, перевезли на Подільське торжище «и повергоша поруганью». Засуджуючи дії міського плебсу, київський літописець свідчив про те, що благовірні кияни, «приходяще изимахоу от крове его и от прикрова соущего на на немъ. на тьль его . на спасение себе . и на исцьление» ${ }^{48}$. Це повідомлення засвідчує сакральний статус княжого вбрання. Уявлення про значущість одягу середньовічних монархів були вельми поширеними за середньовіччя. Для простолюдина доторкнутися до краю одежі володаря чи навіть до упряжі його коня вважалося винятковою удачею. Коли таке вдавалося вчинити засудженому на кару злочинцеві у середньовічній Німеччині, його очікувало помилування ${ }^{49}$. Прилучення до харизми живого чи мертвого володаря, його одягу було також нормою культурної практики середньовічної Русі. Підтвердження цьому знаходимо в поширеній практиці зберігання вбрання «блаженних первых князьи» в головних храмах. Сповіщаючи про велику пожежу, що спалахнула у Владимиріна-Клязьмі, Лаврентіївський (під 1185 р.) та Іпатіївський (під 1183 р.) літописи повідомляли, що згоріло мало не все місто разом із княжим подвір'ям, багато церков, у тому числі «сборная церкви святая Богородица Златоверхая [...] и что бяше в неи : и дну оузорочи . и поникадила серебреная . и судъ златых и сребреныхъ бещисла . портъ шитыхъ золотомъ и женчюгомъ яже вьшали на праздникъ въ двь верви от Золотых ворот до Богородицъ» ${ }^{50}$. Серед розграбованого монголо-татарами в 1237 р. дорогоцінного начиння цього храму - ікон, посуду та книг згадуються й «порты блаженних первых князьи, еже бяху повьшали в церквах святых на память собъ» ${ }^{51}$. Цей опис має характер пізнішої вставки, запозиченої з реалій учиненого 1203 р. в Києві Рюриком Ростиславичем і союзними йому військами чернігівських Ольговичів нечуваного доти погрому:

«Взят бысть Кыевъ Рюрикомъ о Ольговичи . и всею Половецкою землею . и створися велико зло в Русстъи земли . якого же зла не было от крещенья надъ Кыевомъ [...] не токмо одно Подолье взяша и пожгоша ино Гору взяша . и митрополью святую Софью разграбиша . и Десятинную святую Богородицу разграбиша . и манастыри всь . и иконы одраша . а иныђ поимаша . и кресты честныя и ссуды священыя . и книгы и порты блаженых первых князьи . еже бяху повђшали в церквах святыхъ на память собъ»52.

Практику зберігання вбрання «перших» руських князів, що виступало окрасою храму, було запозичено, як умотивував О.П.Толочко, із візантійської традиції пошанування шат та інсигній влади першого християнського володаря у соборі Св. Сoфiї в Константинополі:

\footnotetext{
47 Ипатьевская летопись. - Т.2. - Стб.351-352.

48 Там же. - Стб.353.

49 Бойцов М.А. Власть правителя // Словарь средневековой культуры / Под ред. А.Я.Гуревича. - Москва, 2003. - C.90.

50 Ипатьевская летопись. - Т.2. - Стб.630.

51 Лаврентьевская летопись. - Вып.2: Суздальская летопись по Лаврентьевскому списку // ПСРЛ. Т.1. - Стб.463.

52 Там же. - Стб. 418.
} 
«У візантійській теорії відправним пунктом вселенської влади імператора розцінювалося правління першого царюючого християнина Константина. Згідно з традиціею, його вбрання було не витвором рук людських, але надіслане Богом через ангела, що звелів "покласти їх до Великої святої церкви, яка ім'ям самої істинної мудрості Божої святою Софіею нарікаеться". Цьому вбранню надавалося майже містичне значення. Підвішене над святим престолом у вівтарі храму воно було його прикрасою. Інші царські шати й облачення розгорнутими покладено поверх святого престолу - вони служили свого роду символом і речовим доказом супрематії імператора у християнському світі» ${ }^{53}$.

Візантійські імператори подеколи могли на знак особливої прихильності дарувати свій одяг якомусь місту, і тоді це вбрання врочисто вивішувалося в головному міському храмі ${ }^{54}$. Можна обережно припустити, що так само й у збудованій у Киеві хрестителем Русі Десятинній церкві, а пізніше у храмі Св. Софії зберігалося щось із парадного одягу перших «блаженних князів» - одруженого з грецькою «цесарівною» Володимира Великого та Ярослава Мудрого. Ці речі мали не тільки меморіальне, але і прикладне значення: їх могли використовувати під час проведення церемоніалів, зокрема обряду великокнязівської інтронізації. Якусь частину цих реліквій пізніше привласнив Андрій Боголюбський, поклавши їх за київською традицією до збудованого ним у Владимирі Богородичного храму. При собі він завжди мав напохваті меч молодшого Володимирового сина - князя-страстотерпця Бориса ${ }^{55}$ (який, однак, не врятував його від заколотників).

Приготовлене на різні випадки буденного життя, для врочистих церемоній i ритуалів пишно оздоблене вбрання, аксесуари і крам разом із золотими та срібними монетами складали основний вміст князівської скарбниці. Після вокняжіння в Киеві Ізяслава Мстиславича і його стрия В'ячеслава, вони щедро винагородили союзних угрів. Серед дарів було й дороге вбрання та паволоки: «Изяславъ велику честь створиста Оугромъ . Вячеславъ же от себе а Изяславъ же от себе . и дарми многыми одариста и съсуды и порты . и комонми и паволоками . и всякими дарми» ${ }^{56}$.

Розповсюджена за середньовіччя практика роздачі подібних дарів являла собою «вищою мірою істотний зріз соціальних зв'язків, включаючи й певні емоційні, релігійні та навіть магічні аспекти. Відносини між індивідами і групами були не анонімними, і дари сприяли встановленню й підтримці дружби та побратимства між окремими особами або сім'ями, мирного добросусідства між племенами й політичними об'єднаннями» ${ }^{57}$. Князь і дружина щільно пов'язувалися світом речей, які були згустком відносин між ними та еднали їх спільною причетністю до елітарного співтовариства лицарів-воїнів.

Убрані в добротні обладунки князі разом зі своїми міністеріалами і дружинниками помітно вирізнялися на тлі сірого й буденного одягу простолюду, одноманітних строїв чорного або білого духівництва. Символіка елементів одежі, палітра кольорів разом з іншими знаковими засобами середньовічної ментальності «призводили до узгодження індивідуальних устремлінь з інтересами груп і суспільства у цілому, забезпечували соціальні комунікації, обмін образною та словесною інформацією» ${ }^{8}$.

\footnotetext{
53 Толочко А.П. «Порты блаженных первых князей»: к вопросу о византийских политических теориях на Руси // Южная Русь и Византия. - К., 1991. - С.36.

54 Грабар А. Император в византийском искусстве. - Москва, 2000. - С.25-26.

55 Див.: Ипатьевская летопись. - Т.2. - Стб.586-587.

56 Там же. - Стб.419.

57 Гуревич А.Я. Дары. Обмен дарами // Словарь средневековой культуры. - С.129.

58 Даркевич В.П. «Градские люди» Древней Руси: XI-XIII вв. // Из истории русской культуры. - Т.1 (Древняя Русь). - Москва, 2000. - С.643.
} 
Полиск обладунків дружинників волинського князя Василька, побачений угорським королем Андрашем у 1231 р. на стінах Володимира, вразив уяву цього монарха. Він, за словами літописця, визнав, що такого міста не знаходив навіть у німецьких землях: «Яко така град не изобрьтохъ ни в Нђмъчкыхъ странахъ . тако соущоу оуружьникомъ стоячим на немъ . блистахоуся щиты и оружьници подобни солнцю» ${ }^{9}$. А для київського книжника початку XII ст. пам'ятним стало вбрання ватажка варязького загону Якуна, який у 1024 р. виступив на боці Ярослава Мудрого проти Мстислава Тмутороканського: «И бъ Якун сь льпъ . и луда бъ у него золотом истъкана». Під час втечі з поля бою Якун загубив, а може і свідомо позбувся цієї примітної деталі свого обладунку: «Видъвъ же Ярославъ яко побъжаемъ есть . побъже съ Якуномъ, . княземъ варяжьскым . и Якунъ ту отбъже луды златођ» ${ }^{6}$. Слово «луда» скандинавського походження, перекладаеться і як «золототканий плащ», і як «бойові лати» ${ }^{61}$. У практиці Русі візуальною «мовою» полководця на поді бою було не його примітне вбрання, а прапори з відзнаками княжого «знамянья».

Більшу частину свого життя князь проводив у походах або на полюванні. Війна та лови для аристократичної верхівки середньовічних часів були головним ремеслом, що визначало не тільки притаманну їй програму життевої акції і світогляду, але й стиль одягання. Бойовий обладунок ціеї верстви складали багато оздоблені металеві лати, шоломи, щити, мечі. Вони були предметом особливої поваги в лицарському співтоваристві. Широкої популярності в Русі IX - кінця X ст. набули каролінзькі мечі. Походження більшості з виявлених археологами зразків цієї зброї дослідники пов'язують зі зброярськими центрами Франкії. Широку практику їх розповсюдження засвідчують знахідки у скандинавських, слов'янських, балтських землях. Велика кількість мечів, виявлених у водоймищах Центральної та Північної Європи, а також у річках України, пов'язуеться з жертовними воїнськими ритуалами. Такі речі владно диктували стиль поведінки, жести, ритуали, а в кінцевому підсумку і психологічну установку своїм власникам.

Верховий кінь у дорогій упряжі був своерідним продовженням бойового обладунку вершника ${ }^{62}$. У лицарському етосі - стилі життя провідної верстви суспільства та прийнятій нею іерархії цінностей, скакун важив багато. Показовою у цьому відношенні була поведінка Андрія Боголюбського. Коли навесні 1149 р. загинув його поранений кінь («ять бо бъ двъма копиема под ним конь . а третьимъ въ переднии лук сьделныи»), винісши перед цим свого господаря з самої гущавини запеклого бою під мурами Луцька, князь, «жалуя комоньства его повель и погрести надъ Стыремъ» ${ }^{3}$. Повноцінне життя правителя, призначенням якого була воїнська служба, розпочиналося з обряду посадовлення на коня. Відтоді йому не раз доводилося вступати «въ злата стремень», щоб вирушити в похід. Їздити біля стремені монаршого скакуна було жаданою честю для його васалів. Це, здається, стало нормою феодального етикету й у середньовічній Русі, що засвідчують слова волинського князя Ярослава Володимировича, адресовані великому князеві київському Ізяславові

\footnotetext{
59 Ипатьевская летопись. - Т.2. - Стб.765. Укладачі Галицько-Волинського літопису з поетичним замилуванням описують лицарські обладунки руських «мужів воїнських», порівнюючи, наприклад, полиск їхніх щитів із зорею, а шоломи - із сонцем на сході (див.: ПСРЛ. - Т.2. - Стб.813).

60 Лаврентьевская летопись. - Т.1. - Стб.148.

61 Срезневский И.И. Материалы для словаря древнерусского языка. - Т.2. - Санкт-Петербург, 1895. - Стб.49; Лихачёв Д.С. Комментарии // Повесть временных лет / Подгот. текста, пер., ст. и комм. Д.С.Лихачёва; доп. М.Б.Свердлова; под ред. В.П.Адриановой-Перетц (3-е изд.). - Санкт-Петербург, 2007. - С.479, 623.

62 Див.: Кирпичников А.Н. Снаряжение всадника и верхового коня на Руси IX-XIII вв. [Археология СССР: Свод археологических источников, вып.Е1-36]. - Москва, 1973.

63 Ипатьевская летопись. - Т.2. - Стб.391.
} 


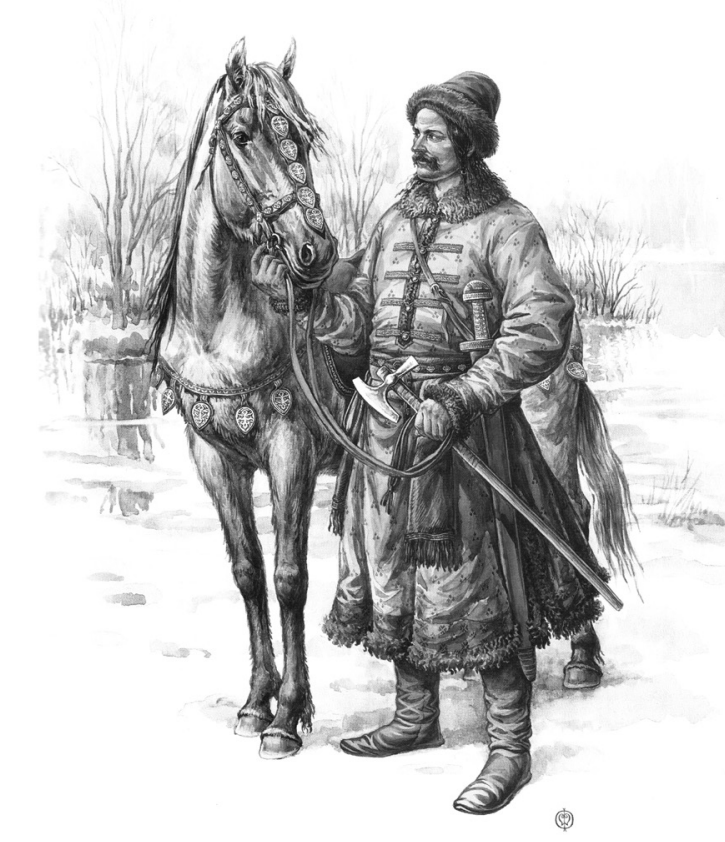

Убрання київського дружинника.

Реконструкція за матеріалами дружинних поховань Х ст. Малюнок О.В.Федорова
Мстиславичу: «Отче кланяю ти ся прими мя яко сына свого Мстислава . такоже и мене . ать ездить Мстиславъ . подль твои стременъ . по одинои сторонь тебе а я по другои сторонь . подль твои стремень . Бждю всими своими полкы» ${ }^{64}$. Утвердження на галицькому столі згадуваного вже боярина Доброслава Суддича стало безпрецедентною подією в давньоруській політичній практиці. Між тим частина галичан визнала, здається, його право на володарювання: «Галичаном же текоущим оу стремени его» ${ }^{65}$. В архаїчних уявленнях середньовічних спільнот влада зазвичай «опредмечувалася», концентрувалася в певних речах. Такою знаковою річчю й були оспівані автором «Слова о полку Ігоревім» «золотії стремена» княжого скакуна.

Захисні обладунки - щит і шолом, прикрашалися різноманітними символами-оберегами, зазвичай зображеннями святих, як, наприклад, шолом київського князя Ізяслава Мстиславича 3 витісненим золотом на ньому зображенням св. Пантелеймона. Як сповіщає

Київський літопис під 1151 р., Ізяслав зазнав поранення в битві з військом Юрія Долгорукого на Перепетовому полі поблизу річки Рути. Коли він отямився й намагався схопитися на ноги, піші київські воїни хотіли його вбити,

Св. Пантелеймон був небесним заступником Ізяслава, на честь якого й отримав це хрестильне ім'я. Одужання в 1097 р. важко пораненого на полюванні його батька - Мстислава (Гаральда), як уважалося, сталося саме завдяки заступництву св. Пантелеймона. У складеному в 1120-х рр. німецьким абатом Рупертом «Слові про святого мученика Пантелеймона» серед описів кількох чудес його вміщено й чудо про одужання «Гаральда короля народу Русі». Із кельнським монастирем Св. Пантелеймона пов'язана його мати - донька останнього англосаксонського короля Гаральда, що була дружиною Володимира Мономаха. Саме завдяки 行

\footnotetext{
64 Там же. - Стб.465.

65 Там же. - Стб.790.

66 Там же. - Стб.438-439.
} 
молитвам до небесного покровителя Мстислав зцілився, після чого запровадив у своєму сімействі пошанування цього святого ${ }^{67}$. На його честь Ізяслав збудував церкву в Новгороді, де сталося одужання у часи батькового князювання там. Ще один храм Св. Пантелеймона нащадки Мстислава наприкінці XII ст. звели в Галичі.

Раніові відмінності дружинників визначали підвіски 3 княжими знаками, що їх носило найближче оточення князя - посадники, тивуни, вірники. Проте сфера їх використання була обмеженою. Час їх активного функціонування припав на період правління Володимира та Ярослава ${ }^{68}$. Носіння золотих іменних перснів із вирізьбленими на них власницькими знаками й медальйонів-амулетів, поширених у Русі від ХІ ст. ${ }^{69}$, було здебільшого прерогативою князя. Частина з них збереглася до наших днів. Такою є золота «чернігівська гривна», виготовлена 1084-1094 рр. для Володимира Мономаха та схожий із нею золотий амулет-змійовик, гаданим власником котрого був його син Мстислав ${ }^{70}$. Шийною прикрасою княжих достойників служили золоті цепи-«чепи». Проте, на відміну від середньовічного Заходу, у Київській Русі не сформувалася розвинута система візуальної геральдичної ієрархії.

Знаковою була роль кодексу вбрання й у поховальних ритуалах. Дорогоцінні покривала та одяг для цього випадку заздалегідь складались і зберігались у забитих скринях. Коли приходив час, небіжчика одягали, «оувиша и оксамитомъ со круживомъ якоже достоить царямь» ${ }^{71}$. Як засвідчують матеріали археологічних досліджень, використовувалися дорогі шовкові тканини із зображенням орлів та інших царських звірів і вигадливих орнаментів ${ }^{72}$. Усе це стало доконечним елементом коронаційних і поховальних церемоній, що розпочиналися з одягання. Убране тіло покійного князя навіть улітку клали на сани та у супроводі процесії мирян i духівництва, що оплакували й відспівували померлого володаря, допроваджували до патронального храму, який зазвичай слугував місцем останнього прихистку. Так, Володимира Святославича, котрий помер у своїй заміській резиденщії у селі Берестовому поблизу Києва 15 липня 1015 р., «възложьше и на сани, везъше, поставиша и въ святеи Богородици, юже бе създалъ самъ» ${ }^{73}$. Тут посеред княжого двору зібралися кияни, аби попрощатися з ним.

Церемоніал поховання князя сповнювався архаїчною символікою. Траурним символом поховального обряду, окрім саней та жалобного вбрання, слугував і встромлений у землю біля гробу спис. Коли в 1152 р. посол київського князя Ізяслава Петро Бориславич прибув до двору раптово померлого напередодні Володимира Володаровича, його зустрів спадкоємець галицького престолу - князь Ярослав, що сидів убраний у «черни мятли и въ клобуць» на батьківському місці. Під час розмови 3 послом Ярослав промовив: «Богъ отца моего понялъ а мене Бог на его мъстъ оставилъ а полкъ его и дружина е оу мене суть . развђ одино копие ю поставлено оу гроба его . а и то в руку моею есть ${ }^{74}$. В архаїчних військово-політичних обрядах східних слов'ян та інших індоєвропейських народів спис наділявся різноманітними культовими й

\footnotetext{
67 Назаренко А.В. Древняя Русь на международных путях: Междисциплинарные очерки культурных, торговых, политических связей IX-XII вв. - Москва, 2001. - С.587-588.

68 Колибенко О., Колибенко О., Тетеря Д., Юрченко О. Підвіска зі знаком Рюриковичів з Переяславщини та деякі роздуми з приводу інтерпретації геральдичних підвісок // Наукові записки з української історії. Вип.20. - Переяслав-Хмельницький, 2008. - С.286.

69 Див.: Николаева Т.В., Чернецов А.В. Древнерусские амулеты-змеевики. - Москва, 1991.

70 Пуцко В.Г. Білгородська гривна // Старожитності Русі-України. - К., 1994. - С.194.

71 Ипатьевская летопись. - Т.2. - Стб.918.

72 Див.: Фехнер М.В. Ткань с изображением львов и птиц из великокняжеской гробницы во Владимире // Новое в археологии: Сборник статей, посвящённых 70-летию А.В.Арциховского. - Москва, 1972. - С.198-201.

73 Лаврентьевская летопись. - Т.1. - Стб.130.

74 Ипатьевская летопись. - Т.2. - Стб.464.
} 
магічними фонкціями ${ }^{75}$. Піднятий догори в руках князя він символізував його владу. У цьому зв'язку характеристичними видаються опоетизовані у «Слові о полку Ігоревім» устремління Всеслава Полоцького скочити на прудкого коня й домчати в Київ, аби діткнутися кінцем списа до золотого столу київського: «Клюками подпръся о кони и скочи къ граду Кыеву и дотчеся стружїемъ злата стола Киевскаго» ${ }^{76}$.

Слідом за гробом князя під час допровадження до місця поховання йшли його дружинники, котрі несли княжий стяг і вели за вуздечку його неосідланого скакуна. Наприклад, у 1171 р., під час перенесення тіла князя Володимира Андрійовича з Дорогобужа для поховання в Києві, ігумен Полікарп звернувся до вишгородського князя Давида Ростиславича з такими словами: «Княже се дружина его не ьдуть с нимъ . а пусти своеђ дружины нъсколко нъ кто ни конь доведа . ни стяга донеса». На що Давид відповів: «Того стягъ и честь съ душею ищьла» ${ }^{77}$.

Улюблений кінь покійного князя, а також деякі речі повсякденного вжитку після поховання передавалися в пожертву храму, де здійснювався обряд поховання та заупокійні служби. Архаїчні релікти цього звичаю відбиває одна 3 новел «Києво-Печерського патерика», в якій розповідалося про молодого київського боярина, чий батько був «пръвый у князя (Ізяслава Ярославича Київського - В.P.) в болярехъ». Коли юнак твердо вирішив назавжди залишити батьківську домівку, аби стати ченцем Печерського монастиря, він

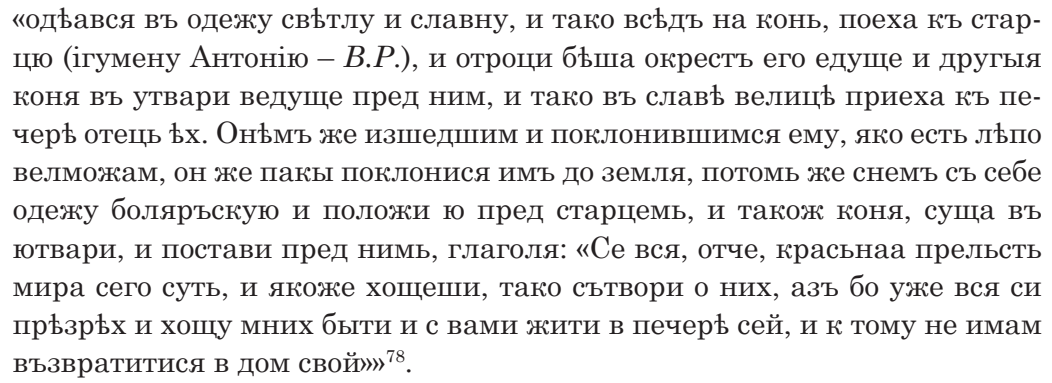

Як бачимо, добровільне прощання з «цим світом» уподібнювалося поховальному ритуалу. Ця «красьнаа прельсть мира сего» - розкішний одяг та осідланий кінь визначали стиль соціально орієнтованої поведінки давньоруського аристократа.

Одяг, речі, якими користувався князь за життя, зберігали свою харизматичну цінність і після його кончини. Так, по смерті постриженика Печерського монастиря в Києві Святослава Давидовича (Миколи Святоші), який народився «величним князем та заради Христа змінив пурпур на власницю» ${ }^{79}$, його брат Ізяслав у 1143 р. «приславъ с мольбою къ игумену, глаголя, прося себе на благословение креста, иже у парамандии его, и възглавница и кладкы его, на неи же кланяшеся. Игумень же дасть ему, рекъ: «По вере твоеи буди тобе». Сей же прием, честно имяше, и вдасть игумену 3 гривны злата, да не туне възметь знамение братьне». Згодом, коли Ізяслав Давидович важко захворів, печерський ігумен передав йому ще й братову волосяницю: «Ту же власяницю взимаше на ся, егда разболяшеся, и тако

75 Чижевський Д. Магічне метання списа // Діалог культур. - К., 1999. - С.295-307.

76 Ироическая песнь о походе на половцев удельного князя Новагорода-Северского Игоря Святославича, писанная старинным русским языком в исходе XII столетия с преложением на употребляемое ныне наречие. Москва, 1800. - С.35.

77 Ипатьевская летопись. - Т.2. - Стб.547-548.

78 Киево-Печерський патерик / Вступ, текст, примітки Д.І.Абрамовича. - К., 1991. - С.32-33.

79 «Патерикон» Сильвестра Косова: переклад та дослідження пам'ятки Н.Сінкевич. - К., 2014. - С.19. 
здравъ бываше. [...] Въ всяку же рать сию власяницю на собе имеаше, и тако без вреда пребываше. Съгрешившю же ему некогда, не сме възяти ея на себе, и тако убиенъ бысть в рати, и заповеда в тои положитися» ${ }^{80}$. Ізяслав помер від ран у Києві 1162 р. та був похований у Чернігові, «в отни ему церкви» свв. Бориса і Гліба.

На спомин душі померлого князя його близькі та родичі роздавали щедрі пожертви храмам і монастирям, а також усім злиденним. Після смерті київського князя Святополка Ізяславича в 1113 р. «княгини же [жена] его . много раздили богатьство . монастыремъ . и попомъ . и оубогымъ . яко дивитися всђмъ человекомъ . яко такоя милости никтоже можеть створити» ${ }^{81}$. Ростислав Мстиславич, поховавши в 1154 р. свого співправителя на київському столі князя В'ячеслава Володимировича у храмі Св. Сoфiï, «еха на Ярославль дворъ и и съзва мужа отца своего Вячеславли . и тивуны . и ключникы . каза нести имънье отца своего передъ ся . и порты . и золото . и серебро . и снесъ все и нача раздавати по манастыремъ и по церквамъ . и по затворомъ и нищим . и тако раздая все» ${ }^{82}$. Важкохворий Володимир Васильковичь напередодні смерті власноруч

\begin{abstract}
«розда убогым имение свое: все золото и серебро, и камение дорогое, и поясы золотыи отца своего, и сербрянье , и свое иже бяше по отци своемъ стяжал все розда: и блюда велика сребрянаа, и кубькы золотые и серебряные самъ пердъ своими очима поби и полья в гривны, и мониста великая золотая бабы своеи и матери своеи все полья и розъсла милостыню по всеи земли, и стада роздая убогым людемь у кого то конии нътоуть [...] Милостыня и дивныя щедроты ко убогым творяше, и к сиротамъ, и к болящимъ, и ко вдовичамъ, и к жадным, и ко всимъ» ${ }^{83}$.
\end{abstract}

Основний зміст цих масових дарувань полягав у тому, аби якомога повно забезпечити спасіння душі померлого князя та його незриму присутність у «цьму світі».

Утилітарний і прагматичний світ речей та вбрання, що оточував середньовічну людину, був наділений знаковим, символічним кодом смислів, значень. Вони сигналізували про належність індивіда до певних соціальних, родинних груп чи профресійних співтовариств. Кодекс убрання визначав не тільки суспільну практику повсякдення, але й соціальну практику, мав здатність ставати своєрідним згустком відносин між людьми та у цій своїй функцї набувати символічного характеру. Притаманний провідній верстві населення Київської Русі стиль одягання й ритуал щоденної поведінки засвідчував їі інтеграцію у традиції лицарства та феодальної культури.

\title{
REFERENCES
}

1. Artsikhovskij, A.V. (1948). Odezhda. Istoriya kultury Drevnej Rusi, Vol.1. Moskva, Leningrad. [in Russian].

2. Bojtsov, M.A. (2003). Vlast pravitelya. Slovar srednevekovoj kultury. Moskva. [in Russian].

3. Brajchevskaya, E.A. (1985). Letopisnye dannye o drevnerusskom muzhskom kostyume X-XIII vv. Zemli Yuzhnoj Rusi v IX-XIV vv. (Istoriya i arkheologiya). Kiev. [in Russian].

4. Chyzhevskyi, D. (1999). Mahichne metannia spysa. Dialoh kultur. Kyiv. [in Ukrainian].

5. Darkevich, V.P. (2000). «Gradskie lyudi» Drevnej Rusi: XI-XIII vv. Iz istorii russkoj kultury, T.1 (Drevnyaya Rus). Moskva. [in Russian].

\footnotetext{
80 Києво-Печерський патерик. - С.117-118.

81 Ипатьевская летопись. - Т.2. - Стб.275.

82 Там же. - Стб.473.

83 Там же. - Стб.914-915.
} 
6. Deivis, N. (2001). Yevropa: Istoriia. Kyiv. [in Ukrainian].

7. Fekhner, M.V. (1972). Tkan s izobrazheniem lvov i ptits iz velikoknyazheskoj grobnitsy vo Vladimire. Novoe $v$ arkheologii: Sb. statej, posvyashchennykh 70-letiyu A.V.Artsikhovskogo. Moskva. [in Russian].

8. Grabar, A. (2000). Imperator v vizantijskom iskusstve. Moskva. [in Russian].

9. Gurevich, A.Ya. (2003). Dary. Obmen darami. Slovar srednevekovoj kultury. Moskva. [in Russian].

10. Kolybenko, O., Kolybenko, O., Teteria, D., Yurchenko, 0. (2008). Pidviska zi znakom Riurykovychiv z Pereiaslavshchyny ta deiaki rozdumy z pryvodu interpretatsii heraldychnykh pidvisok. Naukovi zapysky z ukrainskoi istorii, 20. PereiaslavKhmelnytskyi. [in Ukrainian].

11. Koreniuk, Yu. (2019). Malovidomi aspekty restavratsii mozaik i fresok Sofii Kyivskoi seredyny mynuloho stolittia. Ruthenica, XV. Kyiv. [in Ukrainian].

12. Levchenko, M.V. (1953). Vzaimootnosheniya Vizantii i Rusi pri Vladimire. Vizantijskij vremennik, 7. Moskva. [in Russian].

13. Nazarenko, A.V. (2001). Drevnyaya Rus na mezhdunarodnykh putyakh: Mezhdistsiplinarnye ocherki kulturnykh, torgovykh, politicheskikh svyazej IX-XII vv. Moskva. [in Russian].

14. Nikolaeva, T.V., Chernetsov, A.V. (1991). Drevnerusskie amulety-zmeeviki. Moskva. [in Russian].

15. Putsko, V.H. (1994). Bilhorodska hryvna. Starozhytnosti Rusi-Ukrainy. Kyiv. [in Ukrainian].

16. Sotnikova, M.P. (1968). Srebreniki kievskogo klada 1876 g. Numizmatika i sfragistika, 3. Moskva. [in Russian].

17. Sotnikova, M.P. (1995). Drevnejshie russkie monety X-XI vv. Katalog i issledovanie. Moskva. [in Russian].

18. Sotnikova, M.P., Spasskij, I.G. (1983). Tysyacheletie drevnejshikh monet Rossii. Svodnyj katalog russkikh monet X-XI vv. Leningrad. [in Russian].

19. Tolochko, A.P. (1991). «Porty blazhennykh pervykh knyazej»: k voprosu o vizantijskikh politicheskikh teoriyakh na Rusi. Yuzhnaya Rus i Vizantiya. Kiev. [in Russian].

20. Vysotskij, S.A. (1989). Svetskie freski Sofijskogo sobora v Kieve. Kiev. [in Russian].

21. Vysotskyi, S.O. (1994). Herb Kyivskoi Rusi za chasiv Yaroslava Mudroho. Starozhytnosti Rusi-Ukrainy. Kyiv. [in Ukrainian].

\title{
Volodymyr Rychka
}

Doctor of Historical Sciences (Dr. Hab. in History), Professor,

Chief Research Fellow,

Sector of Research on the History of Kyivan Rus, Institute of History of Ukraine NAS of Ukraine

(Kyiv, Ukraine), wolraukr.net

ORCID: https://orcid.org/0000-0001-8037-4106

\section{Fashion and Ritual: Dress Code in Kyivan Rus}

\begin{abstract}
The article considers the conventional sign systems of the dress code of the leading strata of Rus communities in inseparable unity with the sphere of their activity and behavior. The aim of the research is to study the communicative and symbolic nature of clothing, to understand the phenomenon of fashion in medieval Rus and ideas about the sacred significance of clothing, its role in the rituals of everyday behavior. The methodological basis of the study is the principle of historicism, which is based on the recognition of the relevant semantic isotope of the structures of everyday life, communicative and ideological nature of clothing. The scientific novelty of the work is that it is the first in Ukrainian historiography comprehensive socio-anthropological study of the phenomenon of dress code and fashion as a special type of social communication of Kyivan Rus. Conclusions. The results of the study clarified the communicative and symbolic nature of the dress code. Clothing and related things that surrounded medieval man were not only utilitarian-consumer, pragmatic in nature. They dictated behavior and lifestyle and performed an important social function. The material world of things and, in particular, clothing in the Middle Ages was endowed with a symbolic, symbolic code of certain meanings and meanings and social communications. Each important event in the private and public life of the family, other social groups and professional communities corresponded to his style of dress. The style of dress and ritual of daily behavior inherent in the leading section of the population of Kyivan Rus testifies to its integration into the tradition of chivalry and feudal identity. It is motivated that fashion is not only the world of things and clothes in their external forms, but also gestures, hairstyles, customs, way of life and the whole ritual of daily behavior.
\end{abstract}

Keywords: Kyivan Rus, dress code, fashion, manners, ritual, social communication, traditions of chivalry. 